\title{
Resistência e esperança: lições em tempos de guerra
}

Guilherme Ribeiro

\section{(2) OpenEdition}

1 Journals

\section{Edição electrónica}

URL: https://journals.openedition.org/espacoeconomia/18900

DOI: 10.4000/espacoeconomia. 18900

ISSN: 2317-7837

\section{Editora}

Núcleo de Pesquisa Espaço \& Economia

\section{Refêrencia eletrónica}

Guilherme Ribeiro, «Resistência e esperança: lições em tempos de guerra», Espaço e Economia [Online], 21 | 2021, posto online no dia 12 julho 2021, consultado o 17 julho 2021. URL: http:// journals.openedition.org/espacoeconomia/18900 ; DOI: https://doi.org/10.4000/espacoeconomia. 18900

Este documento foi criado de forma automática no dia 17 julho 2021.

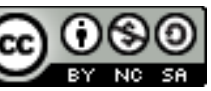

Espaço e Economia - Revista brasileira de geografia econômica est mise à disposition selon les termes de la licence Creative Commons Attribution - Pas d'Utilisation Commerciale - Partage dans les Mêmes Conditions 4.0 International. 


\title{
Resistência e esperança: lições em tempos de guerra
}

\author{
Guilherme Ribeiro
}

1 Tempos indescritíveis - mas não inexplicáveis. Sustentados por quase sessenta milhões de patriotas, Bolsonaro e Bolsonarismo são a mais nova expressão do que há de mais antigo em nossa sociedade: autoritarismo e genocídio, violência e desmatamento, racismo e discriminação. Parido em ambiente dos mais torpes da vida nacional, o militarismo, Jair Messias Bolsonaro conseguiu entrar para a História exatamente como gostaria. No momento em que escrevemos (julho de 2021), o Brasil contabiliza mais de quinhentos mil mortos pela Covid-19. Mesmo em um país acostumado com tantas crises, as vísceras da sociedade brasileira não só estão expostas como vêm sendo celebradas. Envolvendo grupos midiáticos, bancos, agronegócio, partidos políticos, igrejas neopentecostais e frações do Judiciário, o projeto neocolonial e neoliberal da burguesia na periferia do capitalismo exibe suas contradições sem nenhum tipo de pudor, culpa, arrependimento. Pelo contrário. o tom da marcha é o deboche, o escárnio, a cizânia. A tragédia da ampliação da pobreza e da miséria nas grandes cidades brasileiras contrasta com o aumento dos lucros dos mais ricos. E o que dizer, em um dos momentos mais críticos da história, da imobilidade e do silêncio do empreendedor dos empreeendedores, do mais competente dos competentes, do mais apto entre os aptos, os bancos?

2 Tempos indizíveis - mas não impassíveis. Resistência contra o nazi-fascismo e todas as suas modulações, esse editorial quer fazer coro às vozes dissonantes e sustentar em alto e bom som que a história brasileira não terá presente nem futuro enquanto não reconhecer, problematizar e superar sua genealogia escravocrata, autoritária e elitista. De Canudos a Marielle Franco, da ditadura militar aos milicianos cariocas, o que temos é uma nação incapaz de se edificar como sociedade à luz do respeito ao espaço público, da universalização da saúde e da educação, do direito à vida e à cidade. Ao dar as costas à coisa pública, o resultado é a escandalosa concentração da renda e da terra, a perpetuação braudeliana de poucas famílias no poder, o circuito inferior da economia, a mobilidade social sufocada, a naturalização da violência policial estatal, a emergência 
das milícias, a hipocrisia da guerra ao tráfico de drogas, o negacionismo revestido de misticismo pré-moderno, a discriminação contra as minorias em nome da família e das crianças, a coisificação do corpo negro feminino... Todos esses elementos, porém, não são fenômenos excepcionais, isolados ou circunstanciais; eles estão amalgamados em uma grande rede em que uns explicam os outros. Afinal, nossos melhores intérpretes Josué de Castro, Lélia Gonzalez, Milton Santos, Francisco de Oliveira, Sueli Carneiro, Jessé de Souza, para citar apenas alguns - evidenciaram como lição de método que o estudo das contradições sociais passa longe de fórmulas dicotômicas, simplificadoras, deterministas.

3 Tempos inexprimíveis - mas não indolentes. Afinal, que dizer de um país que é capaz de conceber um romance da grandeza de Torto Arado em pleno Bolsonarismo? Obraprima das letras e, se nos permitem, do pensamento social, Torto Arado é uma expressão poética, literária e histórica cujo alcance integral só será reconhecido quando o povo brasileiro for capaz de lê-lo e debatê-lo em casa, nas escolas, em praça pública. Publicado em 2019, como esconder nosso orgulho diante do fato de que Itamar Vieira Junior, seu autor, é geógrafo e funcionário do Instituto Nacional de Colonização e Reforma Agrária? Engendradas no interior do Brasil rural, as comoventes vozes femininas e descendentes de escravas representadas por Bibiana e Belonísia são uma das reações mais poderosas que poderiam ter aparecido exatamente em nossos dias e, desde a Bahia (Vieira Junior é baiano), onde começou a conquista, a posse e o genocídio em 1500, elas nos convidam a repensar o pensamento, a aprender a reaprender, a praticar outras praxis. Espaços, territórios, paisagens, lugares, fronteiras: historicamente ideologizados pelo status quo - a perseguição governamental às Ciências Humanas e Sociais é absolutamente deliberada, ressalte-se -, os conceitos geográficos têm a capacidade de revelar as desigualdades indisfarçáveis as quais indígenas, negros, quilombolas, migrantes, trabalhadores sem terra e sem teto, mulheres e minorias vêm sendo submetidas no transcorrer de cinco séculos. Nesse sentido, no processo ainda embrionário de descolonização do currículo de geografia, a potência espacial (no sentido lato do termo) de Torto Arado faz dele bibliografia primordial (Vieira Junior 2019).

4 Em nome dos demais editores e de todos que contribuem com Espaço e Economia: Revista Brasileira de Geografia Econômica, é com muita emoção que encerramos esse editorial desejando prestar singela homenagem à memória da geógrafa Neli Aparecida de MelloThéry (EACH/USP), cujo passamento ocorreu em abril de $2021 \mathrm{em}$ decorrência de um câncer. Militante e intelectual da causa ambiental, professora generosa e acolhedora, trabalhadora incansável em várias frentes, ao ter como práticas a cooperação em detrimento da competição e a coletividade em oposição ao individualismo, Neli deixa como herança a urgência de construirmos uma universidade e uma sociedade democráticas, transparentes e horizontais. Apoiadora da Espaço \& Economia desde as primeiras horas ao lado de seu marido Hervé Théry (a Confins por eles fundada sempre foi modelo para nós), dela tivemos a chance de publicar Mapeamento do trabalho escravo contemporâneo no Brasil: dinâmicas recentes (Girardi, Mello-Théry, Théry e Hato 2014) e A geopolítica do Covid-19 (Mello-Théry e Théry 2020), sendo aquele o artigo mais acessado de nosso periódico. Agora, mais uma vez, temos a honra e a alegria de editar Iniciativas para mitigação das ilhas de calor em cidades médias: o caso de Jacareí-São Paulo (Mello-Théry, Cavicchioli e Caldas 2021). A ela dedicamos essa edição.

5 Que os valores éticos cultivados por Neli estejam sempre entre nós. 


\section{BIBLIOGRAFIA}

Carneiro, S. (2019). Escritos de uma vida. São Paulo: Jandaíra. 296p.

de Castro, J. (1946). Geografia da fome. Rio de Janeiro: O Cruzeiro. 354p.

de Oliveira, F. (2003). Crítica à razão dualista/O ornitorrinco. Campinas: Boitempo. 150p.

de Souza, J. (2017). A elite do atraso. Da escravidão à Lava-Jato. São Paulo: Leya. 240p.

Girardi, E. P., Mello-Théry, N. A. de, Théry, H., Hato, J. (2014) Mapeamento do trabalho escravo contemporâneo no Brasil: dinâmicas recentes. Espaço \& Economia 4, 1-28. URL: http:// journals.openedition.org/espacoeconomia/804

Gonzalez, L. (1981 [1980]). Racismo e sexismo na cultura brasileira. In: Kemper, A.K. (coord.). Psicanálise e política. Rio de Janeiro: Editora Clínica Social de Psicanálise, 155-180.

Mello-Théry, N. A. de., Cavicchioli, A. Caldas, E. de L. (2021). Iniciativas para mitigação das ilhas de calor em cidades médias: o caso de Jacareí-São Paulo. Espaço \& Economia 21, 1-17.

Mello-Théry, N. A. de, Théry, H. (2020). A geopolítica do Covid-19. Espaço \& Economia 17, 1-10. URL: http://journals.openedition.org/espacoeconomia/11224

Santos, M. (1979). O espaço dividido: os dois circuitos da economia urbana dos países subdesenvolvidos. Rio de Janeiro: Francisco Alves. 345p.

Vieira Junior, I. (2019). Torto arado. São Paulo: Todavia. 264p.

\section{AUTOR}

\section{GUILHERME RIBEIRO}

Departamento de Geografia, Programa de Pós-Graduação em Geografia, Laboratório Política, Epistemologia e História da Geografia, Universidade Federal Rural do Rio de Janeiro. Email: lapehge@gmail.com 